\title{
LA NOCIÓN DEL PODER POLÍTICO EN EL PENSAMIENTO DE LOS JESUITAS ESPAÑOLES DEL SIGLO XVI. UN ACERCAMIENTO DESDE EL CONTEXTO SOCIOCULTURAL DE JUAN DE MARIANA Y FRANCISCO SUÁREZ
}

\author{
Herminio SÁNCHEZ de LA BARQUera y ARROYo* \\ Janet Lucero CERÓN FuENTES**
}

\begin{abstract}
Sumario: I. Introducción: el Renacimiento. II. El contexto cultural y político en la España del Renacimiento. III. Los jesuitas españoles en el contexto renacentista. IV. El padre Juan de Mariana y la idea del poder político. V. El padre Francisco Suárez y la idea del poder político. VI. Conclusiones. VII. Bibliografía.
\end{abstract}

\section{INTRODUCCIÓN: EL RENACIMIENTO}

El Renacimiento es una de las épocas más ricas en lo que respecta a muchos campos del saber y del desarrollo humano: en la filosofía, en el pensamiento político, en las ciencias mecánicas, en el arte de la guerra, en el espíritu de curiosidad científica, en las artes plásticas, en la literatura y en la música. Algunos autores hablan de un "Gran" Renacimiento, para delimitarlo de otros movimientos de renovación cultural y artística que tuvieron lugar a lo largo de la Edad Media, como por ejemplo el nombrado "Renacimiento Carolin-

\footnotetext{
* Doctor en ciencia política por la Universidad de Heidelberg, decano de ciencias sociales en la Universidad Popular Autónoma del Estado de Puebla (UPAEP) y miembro del Grupo de Investigación en Ciencias Sociales (Inciso) de esta misma institución.

** Licenciada en ciencia política por la UPAEP y miembro del Inciso.
} 
gio" de los siglos VIII y IX, llamado también la renovatio carolingia, ${ }^{1}$ o el luminoso siglo XIII. ${ }^{2}$

El Gran Renacimiento es un fenómeno de origen italiano, el cual resulta muy difícil delimitar claramente en el tiempo y en el espacio, ya que se debe considerar para ello tanto el escenario físico como el campo de las actividades y disciplinas humanas de las que estemos hablando. A grandes rasgos, empero, podemos fijar a este periodo entre 1400 y 1600, es decir, abarca aproximadamente los siglos XV y XVI; empero, algunos estudiosos lo sitúan entre 1300 y 1560 , o hasta 1600 ; entre 1330 y 1630 o entre mediados del siglo XIV y finales del XVI. En algunos países, como en Inglaterra, en la península ibérica y en las posesiones portuguesas y españolas en América, encontramos rastros renacentistas incluso en el siglo XVII. ${ }^{3}$

¿Pero por qué el nombre Renacimiento? ¿Quién o qué renace? Renacimiento significa un "volver a nacer" de la imagen del hombre en un encuentro consciente con la Antigüedad, ${ }^{4}$ es decir, el hombre vuelve a ser "la medida de todas las cosas", como dijera Protágoras (ca. 480-410 a. C.). Sin perder la relación con Dios y con el cristianismo, el hombre ahora se orienta en sí mismo, nutriéndose el Renacimiento con la idea del humanismo medieval, cuyas raíces se hunden en el siglo XIII, en lo que Fleming llama "el humanitarismo franciscano": los franciscanos no repudiaron al mundo, sino a las empresas y ambiciones mundanas, y vieron a las criaturas de la naturaleza como "hermanas" del hombre: el hermano fuego, las hermanas estrellas, el hermano lobo. ${ }^{5}$ El fundador de la Orden, San Francisco de Asís (Giovanni di Pietro Bernardone, 1181(82)-1226), inició un movimiento profundamente renovador y reformador caracterizado por una inteligible y nueva relación entre el hombre y sus semejantes, el hombre y la naturaleza, el hombre y Dios.

1 Cfr. Garin, Eugenio, "Einführung: Der Mensch der Renaissance”, en Garin, Eugenio (ed.), Der Mensch der Renaissance, Fráncfort del Meno-Nueva York, Campus Verlag, 1990, pp. 8 y 9.

2 Cfr. Romero, José Luis, La Edad Media, México, Fondo de Cultura Económica, 1994, pp. 141 y ss.

3 Recomendamos al lector curioso, interesado en una visión general de esta época, a Barquera, Herminio S. de la, "El contexto cultural de Nicolás Maquiavelo", en Covarrubias, Israel (ed.), Maquiavelo: una guía contemporánea de lectura sobre lo político y el Estado, México, Taurus, 2017.

4 Ulrich, Michels, Atlas zur musik. Tafeln und text, Múnich, Deutscher Taschenbuch Verlag, 1987, vol. 1, p. 229.

5 Fleming, William, Arte, música e ideas, México, Nueva Editorial Interamericana, 1984, pp. 156 y ss. 
Podemos decir que el hombre renacentista se "(re)descubre" primero a sí mismo, y continúa con la naturaleza y el mundo, contemplándolos de otra manera. Mientras que en el mundo medieval se pensaba en la importancia de cada persona fundamentalmente en relación con su grupo y con el orden general jerárquico, el humanismo renacentista considera a la realización de las capacidades y objetivos individuales muchas veces más importante que la relación con el orden institucional. ${ }^{6}$

El modelo económico sostenido durante la Edad Media, así como las estructuras sociales y políticas, experimentaron en el Renacimiento un proceso de transición que poco a poco fue dejando atrás el viejo esquema económico feudal para ser reemplazado por un incipiente espíritu mercantilista, es decir, nos encontramos frente a los primeros indicios de lo que más adelante será el capitalismo.

En general, el siglo XVI en Europa es definido por Mackenney como una época de expansión y conflicto. ${ }^{7}$ Expansión, porque no sólo España, sino también naciones como Inglaterra, Francia y Portugal logran expandir sus fronteras dentro y fuera del continente, dando como resultado una constante lucha por la supremacía territorial, política y económica. El conflicto se entiende básicamente por las guerras religiosas, que se generaron a raíz de los movimientos protestantes y de la llamada "Contrarreforma", y que a su vez resultaron en expansiones territoriales dentro y fuera de Europa, cuyo objetivo fue la recuperación de viejos territorios para fincar nuevamente el control del dominio espiritual y su influencia en los poderes civiles. En este sentido, el Nuevo Mundo se volvió un blanco indiscutible de la acción de la Iglesia católica, que invirtió un enorme esfuerzo en las tareas de evangelización; además, recordemos que muchos de los más importantes consejeros de los virreyes en los dominios españoles fueron también eclesiásticos.

$\mathrm{Si}$ ahondamos en aspectos culturales y políticos, particularmente en el contexto renacentista español, es menester mencionar que se van a presentar importantes cambios en lo que se refiere a las nuevas ideas políticas del siglo XVI. El Renacimiento en Europa marcó un punto de transición, que va de la Edad Media a la Edad Moderna. Si bien resulta complicado para los historiadores definir claramente la transición de un periodo al otro, en este

6 Véase Müller, Werner y Vogel, Gunther, Atlas baukunst, Múnich, Deutscher Taschenbuch Verlag, 1997, vol. 2, p. 415.

7 Mackenney, Richard, Europa del siglo XVI: expansión y conflicto, Madrid, Ediciones Akal, 1996, p. 89. 
trabajo nos guiaremos a partir de una serie de acontecimientos que marcan la separación de dichos periodos:

a) Descubrimientos geográficos y el nuevo desarrollo comercial, lo cual dio lugar al quiebre de la estructura piramidal sostenida durante el medievo.

b) Los movimientos religiosos de carácter cismático: como se ha mencionado anteriormente, una de las consecuencias importantes de este movimiento fue el debilitamiento de la influencia de la Iglesia católica más allá de los aspectos religiosos. Debemos decir también que, en el ámbito del pensamiento político, estos movimientos lograrán que se desarrolle una nueva interpretación de la sociedad y de la política, dando origen a los estudios de derecho natural, pero dejando a un lado los fundamentos meramente religiosos y desplazando a un segundo término a los teológicos; surgen entonces los "filósofos politizantes" y los "juristas filosofantes".

c) La formación de los Estados nacionales y el desarrollo en la teoría política de una fundamentación de su poder. En este punto es importante señalar que la modernidad se encuentra asociada al nacimiento del Estado; aunque éste como institución tenga sus orígenes en el siglo XIV, se logra configurar de manera importante a lo largo del Gran Renacimiento con la aparición del absolutismo monárquico en Europa. Dicho régimen se logrará sustentar hasta el siglo XVIII. La teoría política del Renacimiento tendría entre sus principales tareas interpretar el origen y fundamento del poder absoluto.

d) El pensamiento político y ascenso del derecho natural. Esto experimentó un auge durante los siglos XVI y XVII, se desarrolló sobre bases filosóficas, teológicas y jurídicas, y se puede apreciar más como teoría política, pues estaba integrado por filosofía práctica. ${ }^{9} \mathrm{El}$ derecho natural del Renacimiento se basa en nuevos planteamientos que comprenden las nuevas situaciones humanas y políticas, propias de los cambios generados por la época. A partir de esta teoría, los nuevos investigadores buscarán, como ya se ha mencionado, com-

8 Según Vallespín, Fernando (comp.), Historia de la teoría politica, vol. 2: Estado y teoría política moderna, Madrid, Alianza Editorial, p. 9.

9 Abellán, Joaquín, "El vínculo entre tradición y mundo moderno. Las teorías políticas del derecho natural (1600-1750)”, en Vallespín, Fernando (comp.), op. cit., p. 13. 
prender, interpretar y explicar el origen y el fundamento del poder. ${ }^{10}$ Las tres razones por las que se facilitó el ascenso del derecho natural fueron: 1) los cambios ocurridos en el método científico del siglo XVII, que impulsaría la búsqueda de una construcción teórica para la explicación y justificación de la comunidad política. El siglo XVII unía la fe en el orden divino del mundo con el nuevo ideal de la ciencia; 2) la crisis, producto de la reforma, demandó la necesidad de un derecho neutralizado, que se asentara en cimientos construidos por encima de las diferencias religiosas, se buscaba una fundamentación del Estado que no fuera religiosa; 3) el ascenso del absolutismo monárquico. Por último, es importante destacar las diferencias entre el derecho natural que sostenían los protestantes y los católicos. Los primeros colocan la interpretación de la naturaleza religiosa como "Dios todopoderoso por encima de ésta", sustentados en la filosofía práctica aristotélica; por su parte, los católicos, y particularmente los nuevos escolásticos, delimitan la voluntad de Dios sobre los hombres. ${ }^{11}$

La orden jesuita (Societas Iesu o Jesu), a la que pertenecieron los dos personajes centrales de este texto, nació a partir de la iniciativa de un personaje español. Esta Compañía de Jesús fue fundada por Ignacio López de Loyola (antes: Íñigo López de Loyola; 1491-1556); el 7 de agosto de 1534, en París, él y unos compañeros más se consagran a Dios. ${ }^{12}$ La institucionalización de la nueva orden no se produjo hasta unos años después, el 27 de septiembre de 1540, cuando el papa Paulo III (1534-1549) la aprobó por medio de la bula Regimini militantes ecclesias. Se definió como una orden moderna en su tiempo, con un elevado carácter renacentista, muy distinto al espíritu medieval de las órdenes más antiguas, tanto de clausura como mendicantes, tales como los benedictinos o los dominicos y los franciscanos. Este carácter adecuado a los tiempos que se vivían se refleja en algunos aspectos importantes: los miembros de la nueva orden no tendrían vida monacal, ni una vestimenta distintiva ni rezarían todos juntos en el coro. En

10 Aún durante los siglos XVI y XVII, el derecho natural tuvo tintes religiosos. Sus impulsores fueron particularmente protestantes (luteranos y calvinistas) y católicos; dentro de estos últimos hay que señalar a la Universidad de Salamanca, a cargo de los jesuitas españoles, que jugó un papel relevante en el desarrollo de dicha teoría.

11 Abellán, Joaquín, op. cit., p. 17.

12 Véase "San Ignacio de Loyola", Jesuitas. Provincia Argentino-Uruguaya, disponible en http://jesuitasaru.org/nosotros/. 
lugar de vivir en monasterios o conventos, vivirían en misiones y colegios, es decir, sin clausura. A diferencia de prácticamente todas las demás congregaciones, la Compañía de Jesús carece de una rama femenina. Además, a los tres votos tradicionales de pobreza, castidad y obediencia agregaron uno más: el de estar siempre a la entera disposición del papa. Producto del pasado militar del principal fundador, la nueva congregación parecía ser una especie de milicia que lucha por Cristo, por lo cual sus constituciones son autocráticas y se rigen por ejemplos y vocablos de la vida del soldado. Además, los jesuitas se destacaron desde el principio por su marcado compromiso con la educación y por su papel en la comprensión del poder político, basándose en el derecho natural.

De esta manera, la nueva orden pronto atrajo a sus filas a personajes sumamente brillantes en cuestiones administrativas y religiosas. No es por eso nada extraño que las escuelas y colegios jesuitas, al igual que los eruditos pertenecientes a la Compañía, se contasen entre los mejores no solamente de Europa sino también del nuevo mundo: sus tareas educativas en la Nueva España, en las numerosas misiones en América del Sur y hasta en los territorios franceses de América del Norte se volvieron proverbiales, máxime que no solamente se concentraron en la atención de una sola clase social, sino que atendían prácticamente a todas.

En el siglo XVI, tan convulso por cuestiones religiosas, los calvinistas desarrollaron una filosofía política ciertamente antimonárquica, pues ven derivar el poder del rey del consentimiento del pueblo, por lo que defienden el derecho de éste a la resistencia. Estas ideas también las podemos encontrar en el campo católico, especialmente entre los jesuitas. Los católicos, al igual que los calvinistas, reciben una influencia marcada por las tradiciones constitucionales, por lo que, al igual que sus adversarios protestantes, también defienden la idea de un gobierno representativo en lugar de uno absolutista. En esto es evidente la influencia medieval. Otro aspecto une a ambos partidos: tanto calvinistas como jesuitas se muestran contrarios a una monarquía nacional demasiado poderosa, pero los jesuitas derivan en un punto diferente al de los católicos más cercanos a los intereses nacionales y dinásticos y al de los calvinistas: el de la supremacía pontificia en cuestiones morales y religiosas. ${ }^{13}$ En otro aspecto, también se distinguen calvinistas y jesuitas: la exposición de la teoría antimonárquica de estos últimos

13 Sabine, George H., Historia de la teoría politica, México, Fondo de Cultura Económica, 1982, p. 287. 
se encuentra en un nivel intelectual más elevado que el de sus contrapartes protestantes. ${ }^{14}$

Podemos decir, siguiendo a Touchard, ${ }^{15}$ que en general los jesuitas comparten las ideas teocráticas heredadas de la Edad Media, si bien, suavizadas a merced de la postura, más sutil, de San Roberto Belarmino (1542-1621), cardenal jesuita, italiano él, autor de obras tales como De summo pontifice (1586) y Tractatus de potestate summi pontifici in rebus temporalibus (1610). Este autor no atribuye al papa la espada temporal, que podríamos caracterizar como soberanía sobre los reyes, sino un derecho limitado que se ejerce con fines espirituales, para poder oponerse a quien ponga en peligro, en el ámbito de lo político, la salud de la cristiandad. Esto es: aunque el papa no tenga autoridad en asuntos seculares, Belarmino es de la idea de que, al ser el jefe espiritual de la Iglesia, tiene un poder indirecto sobre cuestiones temporales, pero exclusivamente para fines espirituales.

Belarmino no considera que el poder de los gobernantes seculares provenga directamente ni de Dios ni del papa, sino de la comunidad para cumplir con sus fines seculares. Esto quiere decir que el poder del monarca es secular por su especie y por su origen; sólo el papa debe su poder directamente a Dios. Consecuencias de estas ideas: los reyes no pueden esperar de sus súbditos una obediencia absoluta, y la autoridad espiritual tiene la facultad de dirigir y regular a la secular para fines espirituales. ${ }^{16}$

Hay que recordar que estamos, en el siglo XVI, ante un panorama político diferente al del medioevo: la res publica christiana ha dejado de ser concebida como un solo cuerpo político, pues ahora está formada por una diversidad de Estados nacionales, autónomos en asuntos seculares, cristianos, pero ya no católicos en su totalidad, pues tributaban fidelidad a diferentes iglesias. Pero el interés superior de la religión exige que la Iglesia tenga un control en asuntos espirituales sobre soberanos, a los que ya no se ve que sean de origen divino, por lo que los jesuitas afirmarán frecuentemente que "la soberanía pertenece al pueblo", aunque esta idea no desembocara en una teoría política. ${ }^{17}$ Sin embargo, fue proclamada con fuerza por el padre Mariana, como veremos más adelante.

Frente a la crisis ocasionada por el movimiento luterano, la Iglesia católica inicia un movimiento para hacer frente a los terribles efectos de la rup- 
tura espiritual del continente. Este esfuerzo recibe un nombre no muy afortunado: la Contrarreforma. ${ }^{18}$ Entre 1543 y 1563, se llevó a cabo el Concilio de Trento, reunión ecuménica de la Iglesia en donde se fijaron los principios católicos frente a las doctrinas de luteranos y calvinistas: condena la libre interpretación y declara dogma las posturas, que con este carácter dicten el concilio o el papa. Se sigue diciendo misa en latín, pero se establece el sermón en el idioma del país; se mantiene el celibato sacerdotal; el sacerdote sigue teniendo el poder sobre los fieles y puede dar o negar la absolución, lo que tiene como base la doctrina petrina, según la cual la Iglesia tiene las llaves del cielo y contempla a los papas como sucesores de San Pedro. ${ }^{19}$

\section{El CONTEXTO CULTURAL Y POLÍTICO \\ EN LA ESPAÑA DEL RENACIMIENTO}

Los jesuitas no son sino papistas puritanos. Jacobo I de Inglaterra

El tardío Renacimiento español transcurre desde finales del siglo XVI hasta mediados del siglo XVII; éste fue el pequeño periodo en el cual podemos asegurar que España se convierte en el epicentro geográfico y político del Viejo Mundo, por diversas razones que ahora explicaremos. El Renacimiento español se caracteriza particularmente por el impulso que recibe la educación con la consolidación de universidades ya existentes (como las de Salamanca y Valladolid), la fundación de otras (como las de Sevilla y Granada) y el gran desarrollo de la vida cultural. Lo último obedece a que ese momento se vio enriquecido por el intercambio cultural gracias a los descubrimientos geográficos emprendidos desde Europa, que además impulsaron el comercio y varias actividades científicas; a esto hay que sumar la cercanía con Italia y los territorios españoles en esa península, que en diferentes épocas fueron: el Ducado de Milán (desde mediados del siglo XVI a principios del XVIII), los Presidios de Toscana (entre 1557 y 1707), el Marquesado de Finale (desde el último cuarto del siglo XVI hasta principios del XVIII) y los reinos de Nápo-

18 Decimos esto porque el movimiento luterano no significó técnicamente una reforma sino un cisma; la reforma vino después, algo tarde ciertamente, y a eso se le llama contrarreforma. En los hechos, empero, ésta fue la verdadera reforma, impulsada, eso sí, por la cruda realidad que luteranos y calvinistas ayudaron a desvelar.

19 Brom, Juan, Esbozo de historia universal, México, Grijalvo, 2013, p. 149. 
les, Sicilia y Cerdeña (desde principios del siglo XVI a principios del XVIII, aunque hay una historia previa de ocupación aragonesa).

Particularmente en el ámbito cultural no podemos evitar hablar del "Siglo de Oro", un excelso periodo de florecimiento de las artes en la península ibérica; aunque no es solamente la literatura la que alcanza cotas altísimas de desarrollo, sino que hay que considerar también a la música y las artes plásticas, generalmente se toma a la literatura como el criterio para fijar aproximadamente su inicio y su terminación: abarca más de un siglo, entre la publicación de la "Gramática castellana" o española de Antonio de $\mathrm{Ne}$ brija en 1492 y la muerte del célebre escritor Pedro Calderón de la Barca, en 1681. Hablamos de manifestaciones artísticas de gran vigor, que influyen en varias regiones como lo son Portugal, Italia, Francia y las colonias españolas en América y en otras regiones del mundo, como las Filipinas.

También la literatura política produjo abundantes frutos, destacando autores juristas y eclesiásticos. Los años finales del siglo XVI y los de principios del XVII fueron testigos de la proliferación de definiciones de la razón de Estado junto a la deslumbrante cima del pensamiento escolástico, teológico y legal, y el vivo debate sobre las fronteras entre religión y política. ${ }^{20}$ Entre los personajes destacados de este género literario podemos nombrar a Baltazar Álamos de Barrientos (1555-1640), Diego Saavedra Fajardo (1584-1648), Jerónimo Castillo de Bobadilla (ca. 1547-ca. 1605), Juan de Solórzano y Pereira (1575-1655) y Francisco Salgado de Somoza (1590/1595-1654). Dentro de la categoría escolástica destacan desde luego los padres jesuitas Juan de Mariana (1536-1624), Francisco Suárez (15481617) y Pedro de Rivadeneyra (nacido en el siglo como Pedro Ortiz de Cisneros, 1527-1611); los teólogos Juan Márquez (agustino, 1565-1621) y Juan de Santa María (franciscano, 1551-1622). En esos tiempos, la influencia de los escritos políticos fue muy importante, pues hacían énfasis en temas como la soberanía política, el origen y fundamento del poder y otros temas muy polémicos, que dieron forma a la época. Se destacan por el realismo político y por la incorporación de doctrinas antiguas y modernas; es así que algunos de estos autores sobresalieron como los fundadores de lo que ahora llamamos "derecho internacional" y "derechos humanos". Ejemplos de estos personajes son el padre Francisco de Vitoria, fraile dominico (1483?-1546), quien influyó de manera notable en Francisco Suárez; fray Bartolomé de las Casas (también dominico, 1474/84?-1566) y el sacerdote Juan Ginés de Sepúlveda (1490-1573). Ambos disputaron vivamente en la

20 Ibidem, p. 101. 
célebre "polémica de los naturales", en Valladolid, en la que también intervino de manera decisiva otro ilustre hombre de letras y de acción: fray Domingo de Soto, O. P. (1494-1560).

Hemos trazado, con esto, una breve reseña que brinde los elementos básicos para entender el contexto en el cual se generaron los cambios que sentaron las bases del Renacimiento español. Debemos entender que todos estos cambios fueron producto de la mentalidad que se comenzó a transformar en Italia, y luego se expandió por el resto del continente desde el siglo XV hasta principios del siglo XVII. El mundo del Renacimiento ciertamente marca el nacimiento de un nuevo hombre, de una nueva cultura, de una nueva forma de hacer, entender e interpretar la política y otros aspectos de la sociedad. La gran tarea para las grandes mentes de los siglos renacentistas no fue otra que buscar una interpretación de los fenómenos de este nuevo mundo a partir de la nueva forma de entenderlo y de acercarse a él.

\section{LOS JESUITAS ESPAÑOLES EN EL CONTEXTO RENACENTISTA}

Un dominico, intrigado, le pregunta a un jesuita: -¿Es cierto que los jesuitas responden siempre a una pregunta con otra?

-¿Y quién le dijo a Su Reverencia tal cosa?

Anteriormente se ha mencionado el contexto político y cultural del Renacimiento en Europa y se ha intentado delinear un poco de lo que sucedía particularmente en España. A modo de resumen, diremos que España fue un punto muy importante para lograr comprender los cambios generados en el mundo moderno, primero por ser protagonista de los nuevos descubrimientos geográficos $\mathrm{y}$, segundo, por su intervención en la formación de una teoría política capaz de explicar los cambios políticos y sociales a los que se enfrentaba el mundo de la época.

El Concilio de Trento y esa nueva orden religiosa denominada "la Compañía de Jesús" supusieron un cambio de rumbo en contra del protestantismo. La constitución de la Compañía de Jesús es una de las herencias que nos deja la Edad Moderna y particularmente el Siglo de Oro español. En este contexto, se "gesta el proceso de ese nuevo grupo religioso los jesuitas. 
Había que enfrentar la realidad nueva con nuevas instituciones y formar a los hombres para las situaciones no acostumbradas". ${ }^{21}$

Marcel Bataillon ha establecido una relación entre esa naciente Compañía y el movimiento general del humanismo cristiano en España, elemento sin el cual no se puede entender gran parte de los postulados e influencia filosófica y política en España y otras regiones de Europa. El significado del humanismo cristiano se debe entender más allá del florecimiento de las humanidades aplicadas al renacimiento de la antigüedad cristiana bíblica y patrística; la importancia central de este movimiento consistió en dar paso a un intenso despertar religioso, por medio del cual el cristianismo fue profundamente renovado y revolucionado durante el siglo XVI. ${ }^{22}$ Lo anterior sin duda fue explotado por los reformadores católicos, particularmente por los miembros de la Compañía de Jesús, como movimiento de reacción frente a los protestantes.

En este punto es importante hacer mención de un personaje y un movimiento que marcaron esta fase en la historia de España en particular, y de Europa en general, e influyó de forma decisiva en el rostro del humanismo cristiano: nos referimos a Erasmo de Róterdam (1466-1536) y al erasmismo. Aunque Erasmo no era español y su movimiento no fue recibido inmediatamente en la península, su impacto impulsó el desarrollo de una conciencia nueva con respecto a la Iglesia. Por el contrario, en los países en donde se consolidaron los protestantes, Erasmo era visto como un corruptor de la opinión, mientras que los más furibundos enemigos de los movimientos cismáticos no dudaron en atribuirle buena parte de la culpa por el estallido de tales acontecimientos religiosos y políticos. Erasmo vivió y aprovechó el inusitado auge de la imprenta en el primer cuarto del siglo XVI, de tal manera que se convirtió en una celebridad y en lo que podríamos denominar un "autor independiente". Obsesionado por los graves acontecimientos a los que su época se enfrentaba, su primera preocupación era sin duda el problema de la paz entre los pueblos, por lo que llegó a predicar el entendimiento entre las religiones. Erasmo fue el teólogo más admirado y al mismo tiempo el más severamente criticado, tanto por católicos como por protestantes. Al irenismo erasmiano, entendible si contemplamos la convulsa época que vi-

21 Beaumont, Guillermo, "Los jesuitas, orígenes, logros y estrategias", en AUSJAL-Universidad Católica Andrés Bello, Cuadernos ignacianos: jesuitas en Venezuela, Caracas, 2005, p. 29.

22 Bataillon, Marcel, Los jesuitas en la España del siglo XVI, México, Fondo de Cultura Económica, 2014, p. 36. 
vió, se remiten sus palabras: "Lo esencial de nuestra religión es la paz y la unanimidad" (Summa nostrae religionis pax est et unanimitas). ${ }^{23}$

Así, en el contexto del siglo XVI en España, tiene lugar una serie de cambios que quedarían plasmados en la historia de las ideas políticas, caracterizados por la fuerte influencia del movimiento renacentista y del humanismo que permeaban en diferentes ámbitos sociales y culturales. Las transformaciones en el ámbito espiritual son el inicio de una nueva conciencia que obligó a la Iglesia católica a reformarse.

De igual manera, en el ámbito del pensamiento político se abrió paso una nueva generación de pensadores, no necesariamente filósofos. Entre las nuevas filas encontramos a juristas y eclesiásticos miembros de la Compañía, que se fortalecía día a día. Su postura frente a la realidad política social y los intereses de la institución que representaban son puntos clave para comprender su postura frente a temas de gran relevancia. Recordemos que la forma de gobierno español era por excelencia la monarquía, sin embargo, los escritos de los estudiosos españoles buscaban dar una justificación al sostenimiento de dicha institución al abordar una serie de temas clave en ese momento.

Por la razón previamente expuesta, durante los siglos XVI y XVII el epicentro de los estudios en torno a la reflexión del poder será la Universidad de Salamanca. Dentro de este contexto tenemos el resurgimiento de la filosofía escolástica o el pensamiento neoescolástico. Este último ocupa un lugar fundamental en la historia del pensamiento político de Occidente, pues fue determinante en el tránsito del universo político medieval (dominado por Santo Tomás de Aquino) al moderno, y a los principios contractualistas que lo orientan después de "la ruptura de los fundamentos escolásticos, desde su propia lógica, que abrió el horizonte para una política basada en la acción de los hombres. Simultáneamente, ese quiebre se produjo en torno a uno de los problemas más determinantes, si no el más importante, que rige la política hasta nuestros días: la diferencia y la relación entre el sujeto y el ejercicio de la soberanía". ${ }^{24}$

Recordemos nuevamente que este contexto comprende el periodo de apogeo de las monarquías absolutas, razón por la cual fue necesaria la creación de un sistema de limitaciones al poder y al mismo tiempo de garantías

23 Cit. por Bataillon, Marcel, Erasmo y el erasmismo, Barcelona, Biblioteca de Bolsillo, 2000, p. 21.

24 Nazareno, Francisco, "Francisco Suárez y los orígenes del pensamiento político moderno", Ingenium. Revista Electrónica de Pensamiento Moderno y Metodología en Historia de las Ideas, núm. 10, 2016, pp. 179 y 180. 
a los súbditos. ${ }^{25}$ En los escritos y tratados políticos de ese tiempo se hacen constantemente hincapié en temas como el origen, el fundamento y los límites del poder, la libertad de los súbditos o el análisis de las normas morales. Al mismo tiempo, comienzan a surgir los llamados "tratados de educación de príncipes", pero, a diferencia de Nicolás Maquiavelo (1469-1527), los tratadistas españoles buscan formar al monarca para que se desarrolle en función de un modo "correcto". Pese a que la mayoría de los escolásticos españoles rechazaban las tesis sustentadas por Maquiavelo, vieron en sus postulados una solución extrema al problema nuclear del saber político, a saber su autonomía o dependencia de la ética y de la religión. ${ }^{26}$

En resumen, los jesuitas españoles del siglo XVI, como fundadores de la orden, van a tener un papel importante en el aspecto cultural y político de su tiempo, particularmente en el ámbito de desarrollo del pensamiento político. Con el resurgimiento de la filosofía escolástica buscarán dan respuesta a uno de los problemas más importantes de su tiempo: el origen y el fundamento del poder, así como también tendrán que delinear los alcances de la influencia de Dios y del papa dentro del quehacer político. Entre los grandes pensadores escolásticos de los siglos XVI y XVII tenemos sin duda a los padres Juan de Mariana (1536-1624) y Francisco Suárez (1548-1617); ambos dictan una noción de poder en la cual concuerdan, si bien en algunos puntos presentan importantes diferencias. Finalmente, es necesario volver a señalar que la filosofía renacentista en España transcurre durante el siglo XVI y parte del XVII. Estrictamente, el siglo XVII ya no forma parte del Renacimiento, pero desde la perspectiva de las ideas políticas viene a ser una continuación sin grandes sobresaltos de las construcciones del siglo XVI. ${ }^{27}$

\section{El PADRE JuAn de Mariana y LA IDEA DEL PODER POLÍ́TICO}

Prefiero un príncipe torpe que oiga, a otro agudo y perspicaz que no admita más que sus propias decisiones.

Padre Juan de Mariana

El padre Juan de Mariana es uno de los grandes pensadores políticos del Siglo de Oro español y crítico en un principio de la Compañía de Jesús. Se

25 Segura, Manuel, "Pensamiento político en el Renacimiento español. Saavedra Fajardo”, en Vallespín, Fernando, op. cit., p. 358.

26 Según Fernández de la Mora, citado en ibidem, p. 359.

27 Ibidem, p. 357. 
distingue entre los pensadores de su tiempo por su filosofía crítica, y por el manejo en los temas selectos del siglo XVI como lo es el origen de la sociedad, origen y fundamento del poder político y el derecho de resistencia, siendo autor de la doctrina del tiranicidio. Profesor universitario de gran fama, tuvo alumnos sobresalientes, como Belarmino, quien asistía a sus cátedras en Roma.

Podemos entender el pensamiento político de Mariana siguiendo cuatro etapas centrales: 1) el origen de la sociedad; 2) origen y evolución del gobierno; 3) el fundamento del poder político; y 4) el tiranicidio como remedio a la opresión política.

El padre Mariana ha sido considerado por muchos estudiosos como un rebelde de su tiempo, debido a la concepción que tiene de la sociedad y del poder, y más aún por su postura frente a la opresión política. Esto último ha sido duramente criticado, sobre todo en Francia, y restringido de alguna manera en España por la Compañía de Jesús. Podemos asegurar que Mariana fue un hombre al servicio de la fe católica, pero siempre distinguió entre la autoridad civil y la eclesiástica, separando el papel que corresponde a lo divino y a la naturaleza humana. ${ }^{28}$

Aunque fue un ferviente defensor de la monarquía, sus tesis se opusieron en todo momento al derecho divino de los reyes y a toda clase de despotismos y absolutismos. Podemos decir, con más precisión, que Mariana y otros colegas jesuitas fueron defensores de la monarquía, pero con ciertas limitaciones al soberano, argumentando siempre que el rey debía respetar y apegarse a las normas constitucionales. Para ellos, el pueblo era el portador natural de la soberanía política, como ya vimos más arriba. El monarca, por lo tanto, tiene ciertas limitaciones, como lo explica sobre todo en una obra fundamental: De rege et regis institutione (1598-1599), en donde, además, se puede conocer y entender su idea del poder político, además de que expone sus ideas sobre el origen y la naturaleza del Estado. En dicho texto afirma que el príncipe no está liberado de la ley ("Princeps non est solutus legibus"), idea contraria a la célebre frase del jurista romano Domitius U1pianus (†228): "Princeps legibus solutus est" (citada en el Digesto 1, 3, 31). El padre Mariana reconoce, por lo tanto, un lugar importante a los poderes locales y concede una extensión especial al control eclesiástico, aunque no en beneficio del papa, sino de los obispos. De rege... es un manual escrito para el rey Felipe III, que contiene una serie de consejos "pragmáticos"

28 Jiménez, Pedro, Filosofia critica del padre Juan de Mariana, Madrid, Universidad Complutense, 2002, p. 49. 
sobre cómo defender la monarquía y la fe católica en un mundo corrupto y peligroso. ${ }^{29} \mathrm{El}$ libro inquietó profundamente a muchos de sus lectores, particularmente por la apología del tiranicidio, lo que alimentó la animadversión de los enemigos de la Compañía de Jesús. ${ }^{30}$ El mismo general de la orden religiosa, Claudius Acquaviva (1543-1615), condenó algunas ideas del padre Mariana, cuyos últimos años de vida se vieron ensombrecidos por el proceso que la Inquisición le abrió para revisar sus escritos. ${ }^{31}$

Vale la pena mencionar que el pensamiento de Juan de Mariana se encuentra influido por San Agustín, quien fuera una de las autoridades religiosas y políticas más importantes en el contexto de los conflictos religiosos del siglo XVI (recordemos que Martin Luther era monje agustino). De San Agustín adopta la visión pesimista del hombre y de la política, esta última como herramienta corrupta pero necesaria para salvaguardar el orden social.

La doctrina del padre Mariana recibe también influencias de ideas de tipo constitucional; su argumento sobre el apego a las leyes y a la autoridad lo hacen evidente. La construcción de la teoría de Mariana se basa en la explicación del origen de la sociedad civil, que parte de un estado de naturaleza anterior al gobierno, en el que los hombres vivían en una especie de existencia animal, sin los vicios ni las virtudes de la vida civilizada. ${ }^{32}$ Mariana entiende el origen de la sociedad como un proceso natural, producto de las necesidades humanas de protección. A este punto, Braun añade que para el pensador jesuita "la sociedad civil no es resultado de una sociabilidad natural que sobreviviera a la caída del hombre relativamente indemne, sino el efecto indirecto del pecado original. En realidad, sólo por haberse visto obligados a vivir juntos para defender sus vidas y familias pudieron los hombres ser conscientes y querer, en primera instancia, practicar la caridad y la amistad". ${ }^{33}$

Una vez establecida la sociedad civil, surgió la necesidad del establecimiento de un gobierno que fue a su vez producto de un pacto social que radicaba en la naturaleza humana, en el derecho natural y por tanto en Dios,

29 Braun, Herald. E., "Juan de Mariana, la antropología política del agustinismo católico y la razón de Estado”, Criticón, núm. 118, 2013, p. 101.

30 Touchard, Jean, op. cit., p. 225.

31 Véase Rachum, Ilan, Enzyklopädie der Renaissance, Zúrich, Edition Atlantis, 1985, pp. 327 y 328 .

32 Sabine, George H., op. cit., p. 290.

33 Braun, Herald E., op. cit., p. 104. 
su autor. ${ }^{34}$ El establecimiento del gobierno, y a su vez, el pacto social, dan paso a otro de los temas más importantes que estuvieron presentes en el siglo XVI y tuvieron su resonancia en el XVII, el origen del poder político. Una vez que se encuentra establecido un gobierno, en el caso de Mariana (y para los jesuitas, en general), la mejor forma de gobierno es la monarquía. Para él, los monarcas no pueden reclamar sin más que la suprema potestas se defina y justifique en términos de la ley natural. ${ }^{35}$ Nuestro autor percibe a la monarquía como un fenómeno histórico, enraizado en la ley natural. Dice Mariana, con respecto a esto, que algunos pueblos tomaron la decisión de dejar todo el poder en manos del monarca sin limitaciones, lo cual como lo habían mostrado experiencias históricas había sido lamentable; otros en cambio han optado por delegar el poder, pero con ciertas limitaciones. Lo anterior dio paso a reflexionar sobre el origen del poder: ¿tiene su origen en el rey o en el pueblo? Es decir, ¿es dado por Dios directamente al monarca o al pueblo? Tanto Mariana como Suárez concuerdan en que el poder tiene su origen en Dios, pero son los hombres quienes deciden a quién entregarle ese poder.

El establecimiento del pacto entre soberano y sociedad civil da el poder a la sociedad para deponer al gobernante en caso de que éste oprima políticamente a aquélla. La aceptación del tiranicidio como remedio a la opresión política es una de sus tesis que despertaron — y despiertan — más polémicas y críticas.

\section{El PAdRe Francisco SuÁReZ y la ideA Del PODER Político}

La comunidad política es libre por derecho natural y no está sujeta a ningún hombre fuera de ella, sino que ella misma en su totalidad tiene el poder político que es democrático mientras no se cambie.

Francisco Suárez

Francisco Suárez nació en Granada en 1548; su ingreso a la Compañía de Jesús fue a temprana edad y logró desempeñarse como jurista y teólogo en diferentes universidades españolas. Sus dos obras más importantes son $D e$ Legibus ac Deo legislatore (Las leyes), de 1612, y la Defensio fidei catholicae et apostolicae adversus anglicane sectae errores (Defensa de la fe),

\footnotetext{
34 Jiménez, Pedro, op. cit., p. 78.

35 Braun, Herald E., op. cit., p. 106.
} 
publicada en 1613. Ambos escritos son de carácter jurídico y político, e influyeron en la construcción de la teoría política del poder en cuanto a su origen y fundamento.

Al igual que sus colegas de la Compañía, Suárez fue fiel a la tradición aristotélico-tomista, pero diseñó su propio método: "un sistema de derecho natural más complejo que el de sus contemporáneos, que le permitió una adaptación a las cambiantes estructuras sociales y que puede suministrar un fundamento para la teoría política, que no necesita ya propiamente de una legitimación divina" ${ }^{36}$ Una de las más importantes contribuciones que hay que resaltar es la separación entre lo político y lo divino, que si bien Maquiavelo ya había marcado, son los escolásticos españoles quienes le dieron continuidad, aunque sin olvidar su lealtad a la Iglesia.

Sus enseñanzas marcaron el inicio de una corriente intelectual, conocida como "suarismo", que a lo largo de más de un siglo influyó poderosamente en el pensamiento de las universidades europeas. En este sentido hay que señalar su obra Disputationes Metaphysicae (1597), en la que toca el problema de la voluntad humana y de la idea de lo general contra lo individual, apoyándose sobre todo en Aristóteles y en Santo Tomás de Aquino. Este hombre, de impresionante erudición, puede ser considerado como el más moderno de los escolásticos, por lo que es llamado Doctor Eximius et Pius.

Bajo su propio método, Suárez desarrollará su teoría a la luz del derecho natural, explicando tanto la naturaleza del hombre como la de la sociedad en su aspecto más puro; posteriormente justificará la existencia de la comunidad política y la necesidad de los hombres de vivir bajo un gobierno. El punto central en esto último será quién y de qué manera obtendrá el poder para gobernar.

Suárez, en contraste con el padre Juan de Mariana, no comparte la visión pesimista sobre la humanidad; para aquél, los hombres son buenos por naturaleza. Según los postulados suarecianos, desde su origen los hombres viven en un estado de naturaleza que les permite ser libres, iguales e independientes, lo cual implica que nadie tiene ninguna jurisdicción política sobre nadie; es decir, los hombres viven sin leyes sustantivas. Sin embargo, llega el momento en que los hombres tienen que convivir con diferentes grupos, puesto que es natural que vivan en sociedades. En esto, sigue al principio aristotélico de que el hombre es un animal social por naturaleza. Bajo este argumento, Suárez denomina a la comunidad social como aquel espacio de convivencia entre los hombres que existe aún con ausencia de leyes.

36 Abellán, Joaquín, op. cit., p. 29. 
La condición natural del hombre es social pero no política. Entonces, ¿cómo se logra la transición de la comunidad social a la comunidad política? Para dicho autor, la comunidad social es imperfecta referida a la casa particular (al frente se encuentra el padre de familia), la cual tiene limitaciones al momento de conseguir la felicidad humana. En contraste, la comunidad política se define como la comunidad perfecta, que se gobierna por verdadera jurisdicción dotada de fuerza coactiva, que es la que dan las leyes. ${ }^{37}$ La comunidad política tiene el poder de albergar a los hombres en su conjunto y someterlos a vivir bajo leyes que permitan la sana convivencia.

Hasta aquí se ha mostrado cómo se va configurando una sociedad cada vez más compleja que necesita de estructuras fuertes para garantizar la convivencia de los hombres; por lo tanto, la comunidad política es una necesidad de los hombres para garantizar su supervivencia. Surge, empero, otro dilema: ¿Quién o quiénes tendrán que regir a la comunidad perfecta? ¿Quién tiene el poder en la comunidad? ¿Cómo recae el poder de la comunidad en ese hombre o grupo de hombres?

Lo primero que aclara Suárez, al momento de tocar el tema del origen y destino del poder, es que en definitiva proviene de Dios, pero no le es dado inmediatamente a ningún hombre en particular para el dominio de otros hombres sin tener que rendir cuentas a nadie, más que al Creador. Este punto es muy importante pues es aquí en donde rompe con el supuesto del derecho divino de los reyes. En sus obras mencionadas anteriormente, Suárez aborda el tema del poder político y los dilemas expuestos. En primer lugar, asume que en virtud del derecho natural el poder reside en la comunidad humana. El poder de la comunidad política es un poder que reside en los hombres mismos, pero no se da en cada uno de ellos ni en alguno en particular sino en el conjunto. En conclusión, "el poder se halla en la comunidad por entrega inmediata de Dios, y de esta forma la comunidad lo transfiere al soberano para que haga uso de él como verdadero dueño y como quien lo tiene en virtud de su cargo". ${ }^{38}$ Esto significa que el poder no le es dado al soberano directamente por Dios, sino mediante la voluntad y condición humana que se basa en el contrato de sujeción, el cual avala la transferencia del poder al monarca o soberano, con la intención de que el pueblo tenga un título para oponerse a la tiranía en caso de ser necesario, pues en el pueblo

\footnotetext{
37 Ibidem, p. 31.

38 Nazareno, Francisco, op. cit., p. 119.
} 
reside la autoridad política original, recibida de las manos de Dios, por lo que posee el derecho a la vida y a la libertad. ${ }^{39}$

Con estas ideas, Suárez critica el proceder de los conquistadores españoles en América en su libro De Bello et de Indis (De la guerra y de las Indias), en el que explica que debemos considerar a las Indias occidentales y a los territorios limítrofes como Estados soberanos y, por lo tanto, de la misma categoría que España. En ello vemos no solamente a Suárez teólogo, uno de los más importantes de su época, sino también a Suárez como uno de los fundadores del derecho internacional, ya que, según él, todos los Estados son miembros de una misma comunidad, por lo que las relaciones entre ellos deben ser reguladas por este "derecho de las naciones". ${ }^{40}$

Como se puede apreciar por la delimitación temporal del contexto histórico de nuestro autor, su obra tuvo un impacto importante porque se origina durante la discusión sobre la soberanía en Europa. Es en su obra Defensa de la fe en donde debate con el rey Jacobo I de Inglaterra, sobre su defensa de la doctrina sobre que el poder político es dado directamente por Dios al soberano. Para el rey inglés representaba un problema que el poder se instituyera primero en la comunidad y que ésta posteriormente lo delegara a un hombre. Según Jacobo I, esto podría causar levantamientos en contra del soberano, en su mayoría sin justificación.

En respuesta al monarca inglés, Suárez argumentó que el poder que la comunidad delega al rey queda a resguardo de un pacto, cuya naturaleza se basa en la obediencia del soberano a la administración de la república que le es confiada. En caso de que el monarca no cumpliera en el ejercicio del poder, la comunidad tiene la capacidad de levantarse en contra de él. ${ }^{41}$

Según el erudito James Brown Scott (1866-1943), Suárez completó la obra de Francisco de Vitoria desde el aspecto filosófico y del derecho internacional. ${ }^{42} \mathrm{~A}$ su vez, el renombrado obispo y teólogo Jacques-Bénigne Lignel Bossuet (1627-1704), célebre por su arte oratoria, decía sin ambages

39 Rachum, Ilan, op. cit., p. 510.

40 Idem.

41 Nazareno, Francisco, op. cit., p. 186.

42 Para tener un panorama de las aportaciones riquísimas de Scott en el campo del derecho internacional, de su historia, y particularmente de su concepción en torno al "origen español del derecho internacional", así como de su admiración por Suárez y Vitoria, recomendamos http://www.filosofia.org/ave/001/a355.htm. Scott era dueño de una amplia cultura cosmopolita y abierta, digna del mayor encomio. Para acercarse a estos orígenes del derecho internacional, desde diversas perspectivas, recomendamos Barban, Gustavo (comp.), Fundadores del derecho internacional, Salta, Argentina, Universidad Católica de Salta, 2016. 
que los escritos de Suárez contenían la totalidad de la filosofía escolástica. Grotius (Hugo de Groot, 1583-1645), por su parte, reconoció a Suárez como uno de los teólogos y filósofos más grandes y profundos. Suárez es, por lo tanto, al lado de Vitoria y del mismo Grotius, uno de los fundadores de lo que hoy llamamos derecho internacional. Recordemos que este escritor neerlandés es autor del primer tratado sistemático de dicha disciplina, llamado De iure belli ac pacis, publicado en 1625.

No cabe duda que René Descartes (1596-1650), quien por cierto recibió su educación en un internado de los jesuitas, también muestra una fuerte influencia de Suárez. En la misma situación están la metafísica de Gottfried Wilhelm Leibniz (1646-1716) y los idealistas alemanes ${ }^{43}$ El concepto de "substancia" de Baruch Spinoza (1632-1677) tiene su origen en Suárez; la teoría de la distinción modal del jesuita español adelantó a la de Gottfried W. Leibniz (1646-1716); su ius Gentium, al "contrato social" de JeanJacques Rousseau (1712-1778), y el "sujeto trascendental" de Immanuel Kant (1724-1804) se inspiró en la noción de analogía de atribución descrita por Suárez. Por si esto fuera poco, su concepto del carácter democrático del poder impulsó el Ensayo sobre el gobierno civil (1689) de John Locke (1632-1704).

Los teólogos españoles de los siglos XVI y XVII vivieron una época en la que había que enderezar las armas del intelecto en contra de dos fenómenos amenazadores: los movimientos protestantes y las pretensiones del poder papal. En el primer punto había diferencias religiosas y teológicas que derivaron en diferencias políticas o de concepción política. En el segundo, había que subrayar la soberanía de una nación católica ante el papa.

En lo que atañe al origen del poder político, no sólo era necesario remarcar la capacidad de los hombres para crear una comunidad política, sino había que demostrar que esta comunidad era necesaria. Suárez veía que el estado natural del hombre era de libertad: su condición natural es por lo mismo social, no política. Pero al vivir en comunidad, los hombres necesitan de una guía que no será ejercida por los ángeles ni por Dios mismo, sino que tiene que estar en manos de hombres. Pero el poder de dominar a otros hombres, o de gobernarlos, no se lo dio Dios a nadie en particular: el poder, en la comunidad política, reside en los hombres mismos en conjunto, no en cada uno de ellos ni en alguno en particular con exclusión de los demás.

43 El periodo del idealismo alemán (también llamado "de la filosofía clásica alemana") se extiende aproximadamente desde la aparición de la Crítica de la razón pura (1781) de Immanuel Kant hasta el fallecimiento, en 1831, de Georg Wilhelm Friedrich Hegel, quien había nacido en 1770 . 
La comunidad, necesitada de que alguien gobierne, tiene la capacidad para darse ella misma esa cabeza. El poder, por lo tanto, reside por su naturaleza en la comunidad, quien lo entrega a un gobernante. Esto quiere decir que se requiere de un consentimiento para que esto ocurra. ${ }^{44}$

\section{CONCLUSIONES}

Los personajes que han sido objeto de nuestras reflexiones en este texto, los padres jesuitas Mariana y Suárez, pertenecen a una época luminosa de España, pero que discurre en medio de muchas zozobras, guerras y problemas de conciencia frente a lo que pasaba, por ejemplo, en el proceso de conquista del Nuevo Mundo. Es una época también que traza líneas entre el mundo medieval, tradicional, que se apaga, y el mundo moderno, renacentista, diríamos hoy, que se consolida. Como hemos visto, en materia, por ejemplo, del derecho de gentes, del derecho internacional, de lo que es el poder y de su naturaleza, estos teóricos supieron aprovechar lo que les legaba el Medioevo, a la vez que miraban hacia adelante, con los ojos del espíritu puestos en lo alto y con los pies bien puestos en la tierra. Los jesuitas españoles no veían con buenos ojos el aumento del poder de una monarquía nacional, incluyendo a la española, pero estaban a favor de la supremacía papal en temas morales y religiosos. Es en el pueblo en donde reside naturalmente la soberanía política, no en el monarca, por lo que no es conveniente entregarle todo el poder, cuyo origen está en Dios. Los hombres deben decidir a quién entregarle ese poder, qué límites imponerle y cuándo reclamarlo de vuelta.

\section{BiBLIOGRAFÍA}

ABELLÁN, Joaquín, "El vínculo entre tradición y mundo moderno. Las teorías políticas del derecho natural (1600-1750)", en VALLESPín, Fernando (comp.), Historia de la teoría política, vol. 2: Estado y teoría política moderna, Madrid, Alianza, 1995.

AUSJAL-Universidad Católica Andrés Bello, Cuadernos ignacianos: Jesuitas en Venezuela, Caracas, 2005.

Barban, Gustavo (comp.), Fundadores del derecho internacional, Salta, Argentina, Universidad Católica de Salta, 2016.

Bataillon, Marcel, Erasmo y el erasmismo, Barcelona, Biblioteca de Bolsillo, 2000.

44 Abellán, Joaquín, op. cit., pp. 30-36. 
Bataillon, Marcel, Los jesuitas en la España del siglo XVI, México, Fondo de Cultura Económica, 2014.

Beaumont, Guillermo, "Los jesuitas: orígenes, logros y estrategias", en AUSJAL-Universidad Católica Andrés Bello, Cuadernos ignacianos: jesuitas en Venezuela, Caracas, 2005.

Braun, Herald E., "Juan de Mariana, la antropología política del agustinismo católico y la razón de Estado", Criticón, núm. 118, 2013.

Brom, Juan, Esbozo de historia universal, 24a. ed., México, Grijalbo, 2013.

Fleming, William, Arte, música e ideas, México, Nueva Editorial Interamericana, 1984.

GaRIN, Eugenio (ed.), Der Mensch der Renaissance (El hombre del Renacimiento), Fráncfort del Meno-Nueva York, Campus Verlag, 1990.

JimÉnez Guijarro, Pedro, Filosofía crítica del padre Juan de Mariana, Madrid, Universidad Complutense, 2002.

MaCKenNeY, Richard, Europa del siglo XVI: expansión y conflicto, Madrid, Ediciones Akal, 1996.

MüLleR, Werner y Vogel, Gunther, Atlas Baukunst (Atlas de la arquitectura), Múnich, Deutscher Taschenbuch Verlag, 1997, vol. 2.

NAZARENo SÁnchez, Francisco, "Francisco Suárez y los orígenes del pensamiento político moderno", Ingenium. Revista Electrónica de Pensamiento Moderno y Metodología en Historia de las Ideas, núm. 10, 2016.

RACHUM, Ilan, Enzyklopädie der Renaissance (Enciclopedia del Renacimiento), Zúrich, Edition Atlantis, 1985.

Romero, José Luis, La Edad Media, México, Fondo de Cultura Económica, 1994.

SABIne, George H., Historia de la teoría politica, México, Fondo de Cultura Económica, 1982.

Segura Ortega, Manuel, "Pensamiento político en el Renacimiento español. Saavedra Fajardo", en Vallespín, Fernando (comp.), Historia de la teoría política, vol. 2: Estado y teoría política moderna, Madrid, Alianza, 1995.

Touchard, Jean, Historia de las ideas políticas, Madrid, Tecnos, 2010.

Ulrich, Michels, Atlas zur musik. Tafeln und text (Atlas de la música. Tablas y textos), Múnich, Deutscher Taschenbuch Verlag, 1987, vol. 1.

VALlespín, Fernando (comp.), Historia de la teoría política, vol. 2: Estado y teoría política moderna, Madrid, Alianza, 1995. 